Review

\title{
Endoplasmic Reticulum Stress in the Diabetic Kidney, the Good, the Bad and the Ugly
}

\section{Robyn Cunard ${ }^{1,2, *}$}

1 Research Service and Division of Nephrology-Hypertension, Veterans Affairs San Diego Healthcare System, Veterans Medical Research Foundation, San Diego, CA 92161, USA

2 Department of Medicine, University of California San Diego, La Jolla, CA 92093, USA

* Author to whom correspondence should be addressed; E-Mail: rcunard@ucsd.edu; Tel.: +1-858-552-7528; Fax: +1-858-552-7549.

Academic Editors: Juan F. Navarro-González and Desirée Luis

Received: 3 February 2015 / Accepted: 31 March 2015 / Published: 20 April 2015

\begin{abstract}
Diabetic kidney disease is the leading worldwide cause of end stage kidney disease and a growing public health challenge. The diabetic kidney is exposed to many environmental stressors and each cell type has developed intricate signaling systems designed to restore optimal cellular function. The unfolded protein response (UPR) is a homeostatic pathway that regulates endoplasmic reticulum (ER) membrane structure and secretory function. Studies suggest that the UPR is activated in the diabetic kidney to restore normal ER function and viability. However, when the cell is continuously stressed in an environment that lies outside of its normal physiological range, then the UPR is known as the ER stress response. The UPR reduces protein synthesis, augments the ER folding capacity and downregulates mRNA expression of genes by multiple pathways. Aberrant activation of ER stress can also induce inflammation and cellular apoptosis, and modify signaling of protective processes such as autophagy and mTORC activation. The following review will discuss our current understanding of ER stress in the diabetic kidney and explore novel means of modulating ER stress and its interacting signaling cascades with the overall goal of identifying therapeutic strategies that will improve outcomes in diabetic nephropathy.
\end{abstract}

Keywords: unfolded protein response; albuminuria; inflammation; mTOR; autophagy 


\section{Introduction}

Diabetic kidney disease (DKD) is the most common worldwide cause of chronic kidney disease and a growing public health challenge [1]. The development of diabetic nephropathy is influenced by a number of factors including genetic and environmental susceptibility, altered glomerular and tubular hemodynamics, epigenetic mechanisms and inflammation. Moreover, the micro- and macro-environment in the diabetic individual is greatly perturbed in DKD leading to the dysregulation of many homeostatic signaling pathways.

The endoplasmic reticulum (ER) is the central site for folding, post-translational modifications, and transport of secretory, luminal and membrane proteins. The ER is also involved in calcium storage and lipid biosynthesis. Over two decades ago investigators observed that the accumulation of misfolded proteins in the ER, induced the expression of glucose-regulated proteins (GRPs) including GRP78/heavy chain binding protein (BiP) [2,3]. Subsequent work revealed that increases in the load of unfolded proteins in the ER, activates a complex signaling pathway - the unfolded protein response (UPR). The UPR increases the folding capacity of the ER by upregulating the mRNA translation of ER chaperones and inhibiting the translation of most proteins. The coordinated activation of these pathways is designed to rapidly reduce the ER load. The UPR is a homeostatic pathway that regulates ER membrane structure and secretory protein processing capacity in a dynamic and coordinated manner [4,5]. When the cell becomes overwhelmed by misfolded proteins, then it is considered the ER stress response. However, it is unclear when cells cross the line between the UPR and ER stress; Rutkowski and Hedge have suggested that ER stress occurs when the ER functions in an environment that lies outside of its normal physiological range.

A number of factors activate the UPR including nutrient excess and deprivation, altered protein glycosylation, reducing agents, changes in ER calcium content, oxidative stress and TLR signaling. The diabetic milieu is associated with aberrant protein folding and activation of the UPR. Bacterial and viral infections and bacterial toxins activate the UPR by a variety of mechanisms (reviewed in [6]). Additionally, microRNAs (miRNAs) modulate the UPR and may play a role in the switch between the homeostatic UPR and ER stress [7-9]. However our understanding of microRNAs and their impact on the UPR remains rudimentary.

\section{Mammalian UPR}

In mammalian cells, there are three major arms of the UPR: (1) protein kinase RNA (PKR)-like ER kinase (PERK); (2) inositol requiring protein-1 $\alpha$ (IRE1 $\alpha$ ) and (3) activating transcription factor-6 (ATF6) pathways. The PERK pathway rapidly attenuates protein translation, whereas the ATF6 and the IRE $1 \alpha$ cascades transcriptionally upregulate ER chaperone genes that promote proper folding and ER-associated degradation (ERAD) of proteins, allowing the folding machinery of the ER to catch up with the backlog of unfolded proteins. These pathways are designed to relieve the accumulation of misfolded ER proteins, however when these pathways are overwhelmed by sustained ER stress, the UPR initiates pro-apoptotic pathways [10-14]. The UPR is also associated with adaptive processes such as IRE-dependent Decay (RIDD) and MicroRNA-dependent gene silencing [7,8]. 
GRP78/BiP is an ER chaperone protein that activates the UPR. In unstressed cells, GRP78/BiP binds to the ER luminal domains of the ER stress sensors: IRE1 $\alpha$, PERK and ATF-6 and maintains them in an inactivated state $[15,16]$. During ER stress, BiP preferentially binds to unfolded and misfolded proteins and dissociates from the transmembrane sensors, facilitating their activation. After BiP dissociation, it is not clear whether full activation of the UPR requires subsequent binding of unfolded proteins to the luminal domains of IRE1 $\alpha$, PERK and ATF-6 (reviewed in $[17,18]$ ).

\section{PERK Pathway}

PERK is a transmembrane protein with an ER luminal stress-sensing domain that binds GRP78/BiP, and a cytosolic kinase domain [15]. When ER stress is sensed, PERK multimerizes and phosphorylates eukaryotic translation initiation factor $2 \alpha(\mathrm{eIF} 2 \alpha)$ [19]. Phosphorylation of eIF2 $\alpha$ initially suppresses the translation of $90 \%$ of cellular mRNAs by interfering with $5^{\prime}$ cap assembly $[5,19,20]$. However, a subset of genes including activating transcription factor-4 (ATF4) [19] and nephrin [21] are preferentially translated when eIF $2 \alpha$ is phosphorylated (p-eIF2 $\alpha$ ). ATF4 a transcription factor, then binds to promoter/enhancer regions to transcriptionally upregulate expression of specific UPR target genes, which include $\mathrm{C} / \mathrm{EBP}$ homologous protein $(\mathrm{CHOP}, \mathrm{C} / \mathrm{EBP} \zeta$, DDIT, growth arrest and DNA damage (GADD) 153) [22-24], GADD34 [25], vascular endothelial growth factor (VEGF) A [26], TRB3 [27], osteocalcin, bone sialoprotein [28], receptor activator of NF- $\mathrm{B}$ ligand (RANKL), E-selectin and genes important in amino acid metabolism [29,30]. Other stress-associated kinase signaling pathways converge downstream of p-eIF $2 \alpha$, thus p-eIF $2 \alpha$ functions to induce an "integrated stress response" [17,29].

\section{IRE1 $\alpha / X$ Box Protein-1 (XBP-1) Pathway}

The IRE1 $\alpha / \mathrm{XBP}-1$ pathway is the most evolutionarily conserved of the ER stress pathways [31]. IRE1 $\alpha$ is a membrane-bound serine/threonine kinase with endonuclease activity [32,33]. When ER stress is sensed GRP78/BiP dissociates from IRE1 $\alpha$ [34] and IRE1 $\alpha$ splices a 26 bp intron from XBP-1. Splicing of XBP-1 induces a translational frame-shift that generates a 54 kd highly active transcription factor, compared with a smaller poorly active unspliced XBP-1 (uXBP) [35,36]. XBP-1 induces the transcription of genes involved in ER maintenance, ER expansion and ER associated degradation (ERAD) [37,38]. Studies suggest that UXBP may negatively regulate the UPR by binding and excluding spliced XBP-1 (sXBP) from the nucleus [39]. However, uXBP is inherently unstable and rapidly degraded in cells [40]. IRE1 $\alpha$ also activates apoptosis signal-regulating kinase (ASK1), c-Jun $\mathrm{N}$-terminal kinase (JNK) and nuclear factor kappa-light-chain-enhancer of activated B cells (NF- $\mathrm{BB}$, reviewed in [41]), which are involved in apoptotic, autophagy and inflammatory pathways [42-46].

$\mathrm{XBP}-1$ is member of the basic leucine finger cAMP Response element (CREB)/ATF transcription factor family and it is ubiquitously expressed. Not surprisingly, in mice XBP-1 deficiency is an embryonically lethal mutation due to liver failure [47]. XBP-1 plays a role in hepatic [48], plasma cell $[47,49,50]$, dendritic [51,52] and effector CD8+ T cell [53] development, however its function in the kidney is poorly understood. XBP-1 preserves cell survival during the UPR, however after prolonged stress the IRE1 $\alpha / \mathrm{XBP}-1$ arm of the UPR is attenuated, sensitizing the cells to apoptosis mediated by the PERK/CHOP pathway [54,55]. XBP-1 regulates the biogenesis and expansion of the 
ER and Golgi, is a key modulator of secretory cell function [47,56] and regulates genes involved in redox homeostasis and oxidative stress responses including catalase [38,57]. XBP-1 regulates VEGFA expression and is directly recruited to the VEGFA promoter under ER stress conditions [58]. VEGFA rapidly activates all three ER stress sensors (IRE1 $\alpha$, PERK and ATF6) and promotes endothelial survival [59]. XBP-1 also regulates hepatic glucose metabolism and the hexosamine biosynthetic pathway [60-62]. In nematodes XBP-1 increases longevity [63] and recent work suggests that XBP-1 binds to Hypoxia-inducible Factor $1 \alpha(\mathrm{HIF} 1 \alpha)$ to promote the growth of triple negative breast cancer [64].

\section{Regulated IRE1-Dependent Decay (RIDD)}

A subset of ER-localized mRNAs encoding secreted and transmembrane ER proteins are cleaved directly by the endonuclease activity of IRE1 $\alpha$. The cleaved mRNAs are then rapidly degraded in a process called regulated IRE1-dependent decay (RIDD) [65-67]. This process may assist the PERK arm of the UPR to reduce the accumulation of misfolded proteins in the ER. RIDD activity may also induce the rapid clearance of microRNAs (miRNA-17, -34a, -96 and -125b) that repress translation of caspase-2, to enhance expression of this pro-apoptotic protein [68]. RIDD activity also activates the Nod-like receptor family, pyrin domain containing 3 (NLRP3) inflammasome and promotes inflammation and programmed cell death [69]. However, the relevance of RIDD activity in the kidney is unknown.

\section{ATF6}

ATF6 is the third ER stress sensor that is bound as an inactive precursor in the ER membrane. During ER stress ATF6 is transported to the Golgi and cleaved by site 1 protease (S1P) and site 2 protease (S2P). Cleavage of ATF6 releases its cytoplasmic bZIP domain [70], which translocates to the nucleus and activates the transcription of target genes which include GRP78/BiP, XBP-1, GRP94, oxygen-regulated protein 150 (ORP150), ER oxidoreductin $\beta$ (ERO1 $\beta)$, p58 ${ }^{\mathrm{IPK}}$ and degradation in ER protein 3 (Derlin 3) [16,36,71-76]. Interestingly, the Golgi localized proteases S1P and S2P also catalyze the proteolytic activation of a group of transcription factors, the sterol regulatory binding proteins (SREBPs), linking the ER stress response with lipid and cholesterol synthesis [77,78]. However, it remains unclear whether the UPR and SREBP pathways function in an antagonistic or synergistic manner [17].

\section{ER Stress in the Kidney}

Investigating the ER stress response in the kidney provides a number of challenges. The kidney has many diverse cell types [79] and the UPR functions in a very cell-type and context-dependent manner modulating different downstream pathways to restore tissue homeostasis [6]. However, the UPR likely plays a more significant role in secretory cells such as podocytes, which secrete many factors including VEGF, cytokines, chemokines and factors that promote glomerular basement membrane integrity [80,81]. Many seminal UPR studies have been performed in undifferentiated murine embryonic fibroblasts (MEFs), which likely do not model function in fully differentiated renal cells. Another challenge is regarding the complexity of the UPR with three known signaling pathways each with its 
own dynamic expression, oscillations and function [5,81]. Questions also remain regarding whether investigators should measure mRNA or protein expression of ER-relevant molecules when investigating the UPR, though it seems prudent to investigate both mRNA and protein expression. Finally, certain paradigms in the field have emerged, that are not consistent. An example is that expression of the transcription factor CHOP inexorably leads to cell death. However CHOP does not promote apoptosis in all cell types [82] and CHOP's biological effects may be dependent on CHOP's binding partner [83] or on the phosphorylation status eIF2 $\alpha$ [84].

\section{Renal Cell Systems}

In murine podocytes hyperglycemia, advanced glycation end products (AGE) and free fatty acids (FFA) induce ER stress and apoptosis, and this can be inhibited by exogenous ER chaperones [82,85-87]. AGE increase intracellular calcium concentrations by releasing ER stores, and by increasing calcium influx of extracellular calcium [85]. FFAs induce GRP78/BiP and CHOP expression. CHOP can mediate apoptosis (depending on the phosphorylation status of eIF2 $\alpha$ [84]) or transcriptionally activate downstream ER stress-associated genes including TRB3 [82,87]. In human proximal tubular cells (HK-2) palmitic acid (a FFA) induces ER stress and this can be blocked with a cannabinoid receptor antagonist [88]. In a human renal tubular cell line (HKC), high glucose conditions increase splicing of XBP-1 and transfection of spliced XBP-1 increases expression of fatty acid synthase and acetyl-CoA carboxlase to promote lipid synthesis [89]. In contrast, in mesangial cells, high glucose conditions reduce spliced XBP-1 expression. Transfection of adenoviral XBP-1 reverses high glucose-induced reactive oxygen species (ROS) production and extracellular matrix (ECM) expression. Whereas, knockdown of intrinsic XBP-1 increases ROS and ECM [90], supporting the renoprotective effects of XBP-1. These contrasting effects of high glucose conditions on XBP-1 splicing further illustrate the variable nature of ER stress responses and their strict dependence on cell type and cellular conditions. In human renal tubular cells (HK-2), ER stress increases oxidative stress and reduces anti-oxidant enzymes by reducing micro-RNA (miR)-205 expression [91]. Likewise in rat renal tubular cells (NRK-52E) Dehydroxymethylepoxyquinomicin (DHMEQ, an NF- $\kappa$ B inhibitor), increases ROS, which rapidly induce all three arms of the UPR [92]. Thus ROS activate the UPR [82,92] and depending on the cellular context and conditions the UPR can either negatively [90] or positively regulate generation of ROS [91].

\section{ER Stress in the Diabetic Rodent Kidney}

Mice with constitutive mutations in ER stress proteins develop diabetes, defects in glucose handling [93-96] and ER Stress induces $\beta$-cell failure [97-99]. Thus studies investigating the functional relevance of these proteins in DKD will need to employ conditional knockout or transgenic expression of key ER stress proteins (PERK, IRE1 $\alpha$, XBP-1, eIF2 $\alpha$ etc.). Akita mice (Ins2 ${ }^{+/ C 96 y}$ ), used in studies of Type $1 \mathrm{DKD}$, have a missense mutation in the insulin gene, which causes accumulation of misfolded insulin, activation of ER Stress and subsequent pancreatic $\beta$ cell failure [100-103]. Mice with a heterozygous constitutive knock-in of a mutant GRP78/BiP have evidence of ER Stress in the kidney, associated with age-related renal tubular atrophy, interstitial fibrosis and glomerulosclerosis [104]. 
A number of groups, including ours have documented activation of the ER stress response in the diabetic kidney [82]. Liu and colleagues were the first to evaluate the ER stress response in a mammalian model of diabetes. In STZ-treated rats $(65 \mathrm{mg} / \mathrm{kg}$ STZ IP once), they demonstrated increased expression of GRP78/BiP in glomerular and tubular cells and enhanced kidney cell apoptosis, CHOP, JNK and caspase-12 expression [105]. In older STZ-treated mice (50 $\mu \mathrm{g} / \mathrm{g}$ STZ for 5-8 injections), GRP78/BiP, CHOP, phosphorylated-PERK and p-eIF2 $\alpha$ were increased in 22 month-old diabetic mice, compared with 9 month-old diabetic and non-diabetic mice. Diabetic CHOP knockout mice also had less proteinuria [106]. These studies consistently observed activation of ER stress in the diabetic kidney, but they did not elucidate whether it was protective or destructive. TRB3 is an ER stress-associated protein that is upregulated by free fatty acids and ROS through the PERK/CHOP UPR pathway [82]. We recently demonstrated that constitutive knockout of TRB3 worsens albuminuria, cytokine and chemokine expression in murine Type 1 diabetic kidney disease [107], supporting the protective effects of ER stress. Further studies in mice with transgenic and conditional knockouts of key ER stress-associated molecules will likely clarify the roles that these complex pathways play in the diabetic kidney.

Spliced XBP-1 is reduced in the renal cortices 8 weeks after STZ treatment in rats (65 $\mathrm{mg} / \mathrm{kg}$ once) [90] and the authors hypothesize that this increases ROS (through nicotinamide adenine dinucleotide phosphate (NADPH) oxidase) and ECM. Our group has also observed lower XBP-1 mRNA expression in diabetic mouse kidneys (STZ and $d b / d b$, unpublished observations), though Chen observed higher spliced XBP-1 protein in renal cortices of $d b / d b$ mice [108]. Interestingly, in hippocampuses of $d b / d b$ mice microarray screening showed lower spliced and unspliced XBP-1 [109]. Variable findings of XBP-1 in the kidneys could be related to poor specificity of commercially available antibodies for XBP-1, highlighting the importance of verifying XBP-1 expression by real-time PCR. It is not clear why XBP-1 expression is downregulated in the diabetic kidney. However ER stress has distinct temporal patterns [107]. XBP-1 preserves cell survival during the UPR, and prolonged stress attenuates the IRE1 $\alpha /$ XBP-1 arm of the UPR, sensitizing cells to apoptosis $[54,55]$. Thus strategies that augment the IRE1 $\alpha /$ XBP-1 pathway may slow or prevent the progression of DKD.

\section{ER Stress in Human Diabetic Kidney Disease}

Few studies have investigated the ER stress response in the human diabetic kidney. Lindenmeyer and colleagues demonstrated that mRNA expression of GRP78/BiP, ORP150/HYOU1, S1P (MBTPS1), calnexin and XBP-1 increase in the kidneys of patients with established diabetes, compared with mild diabetes [110]. In human kidney transplant biopsies performed before implantation, GRP78/BiP was co-expressed with the inflammatory transcription factor NF- $\mathrm{B}$ p65/RelA, suggesting that ER stress (induced by cold ischemia) activates tubular inflammation in human renal allografts [111]. Further studies investigating the impact and role of ER stress in human diabetic kidneys are needed. Wolcott-Rallison disease is caused by autosomal recessive mutations in PERK [112]. In this inherited defect of the UPR, children develop skeletal abnormalities and infantile diabetes. There are reports of renal insufficiency including proteinuria, which could indicate podocyte or tubular epithelial cell dysfunction or prerenal azotemia [113,114]. 


\section{The UPR Interacts with a Number of Signaling Cascades}

\subsection{Inflammation and Immunity}

Studies have demonstrated close links between ER stress activation and inflammation $[115,116]$. Moreover, enhanced inflammation plays a pathophysiological role in the diabetic kidney [117]. NF- $\mathrm{KB}$ drives the transcription of a number of cytokines and inflammatory molecules and all three arms of the UPR modulate NF- $\kappa B$ activity [118-122]. However the IRE1 $\alpha /$ XBP-1 pathway seems to exert the most effect on inflammation and immunity to pathogens, by regulating the development of many inflammatory cell types [49-53] (reviewed in [6]). The IRE1 $\alpha /$ XBP-1 pathway promotes immune tolerance in the gut [123], and may "protect against ER toxicity caused by innate inflammatory pathways" [124]. ER stress generates ROS, which activate cytokines/chemokines to drive many inflammatory responses. In human renal cortical tubular cells glucose deprivation activates the UPR, which promotes the transcription of interleukin (IL)-6, IL-8, tumor necrosis factor (TNF)- $\alpha$, regulated on activation, normal $\mathrm{T}$ cell expressed and secreted (RANTES) and monocyte chemokine protein (MCP)-1 via NF- $\mathrm{KB}$ in an IRE1 $\alpha$-dependent manner [111]. In type 2 diabetic $(d b / d b)$ mice ER stress triggers the expression of MCP-1 by XBP-1-mediated induction of SET7/9 (a histone lysine methyltransferase), which increases histone 3 lysine 4 methylation of MCP-1 promoters in renal cortices of diabetic kidneys [108].

The inflammasome is an oligomer of proteins that activate pro-apoptotic caspases and inflammatory cytokines, and it plays a key role in the innate immune response [125]. During ER stress the IRE1 $\alpha$ and PERK pathways induce thioredoxin-interacting protein (TXNIP), to activate the NLRP3 inflammasome [69,126]. In human biopsies of proteinuric renal disease (IgA nephropathy, minimal change disease, membranous nephropathy, and DKD), inflammasome-related proteins such as caspase 1, IL-1 $\beta$ and IL-18 were expressed in the distal and proximal tubules and expression positively correlated with the degree of proteinuria [127]. In a tubular cellular model (NRK-52E), bovine serum albumin (BSA) induces expression of inflammatory cytokines, NLRP3, GRP78/BiP and phosphorylation of eIF $2 \alpha$. Indeed, use of a chemical chaperone to reduce ER stress attenuates inflammasome activation induced by albuminuria in a murine model of STZ-induced diabetic nephropathy, suggesting that ER stress also activates inflammation and kidney injury [127].

As previously discussed the transcription factor CHOP is classically considered to induce cellular apoptosis. However CHOP may inhibit inflammatory responses in the kidney, as mice deficient in CHOP expression develop more severe septic acute kidney injury (AKI) [128]. In contrast, CHOP's function in chronic kidney disease is not completely understood [106]. Interestingly in human diabetic kidneys CHOP expression was not higher [110], though its expression is consistently augmented in murine models of diabetic kidney disease [82,105,106]. Future studies of ER stress in diabetic humanized rodent models may clarify some of these discrepant findings [129].

Toll-like receptors (TLRs) signal the existence of pathogens and activate the UPR to optimize ER function to facilitate high levels of secretory protein expression [124,130,131]. Indeed fungi and other organisms have used the UPR to provide virulence factors that support their survival in hostile environments [132]. Damage-associated molecular patterns (DAMP) are proteins released outside of the cell or expressed on the plasma membrane in stressed or damaged cells [133,134]. ER stress and 
ROS help traffic DAMPS to the plasma membrane, which recruit innate inflammatory cells to mediate immunogenic cell death. [135,136]. The relevance or existence of DAMP expression in the diabetic kidney has not been established, but it is tempting to speculate that like TLR's, DAMPS may play a pathogenic role in DKD [137].

\subsection{Mammalian Target of Rapamycin (mTOR)}

mTOR is a conserved serine/threonine kinase modulated by growth factors and cellular energy status, and it is a constituent of mTOR complex 1 (mTORC1) and mTORC2. MTORC1 regulates growth, autophagy, survival and metabolism, whereas the role of mTORC2 is incompletely understood. mTORC1 activation in podocytes promotes the development of diabetic nephropathy $[138,139]$ and it is associated with ER stress. The impact of mTORC2 activation in diabetic kidney disease remains unknown. However our group has shown that TRB3, an ER stress-associated protein binds to mTOR and the rapamycin-insensitive companion of mTOR (RICTOR), a protein specific to mTORC2, and inhibits inflammatory cytokine expression [107]. Absence of TRB3 also worsens albuminuria, cytokine and chemokine expression in DKD, another example of the salubrious effects of ER stress [107]. The interactions between ER stress and mTOR pathways is complex and has recently been carefully reviewed [140].

\subsection{Autophagy}

Macroautophagy (referred to as autophagy) is a cellular pathway that preserves homeostasis by degrading long-lived proteins and dysfunctional organelles [141,142]. Autophagy exerts both cytoprotective and cytocidal effects, and dysregulation of autophagy contributes to podocyte dysfunction in diabetic nephropathy [143]. For almost a decade investigators have identified links between ER stress and autophagy. Autophagy may be activated during ER stress to supplement ERAD [46,144,145]. Autophagy can originate from the ER membrane and be triggered by ER stress [44,146-152]. Interestingly in neurons, knockdown of XBP-1 activates autophagy [153], though in neuroglioma cells XBP-1 activates autophagy [154], again highlighting the cell specific effects of ER stress.

The link between ER stress and autophagy in renal pathophysiology was first described in renal tubular cells [155,156]. Podocytes have high levels of autophagy [157] and in cultured podocytes an ER stress inducer tunicamycin (TM), enhances microtubule-associated protein light chain 3 (LC3, a key autophagy protein) [158]. Hartleben and colleagues elegantly demonstrated that podocyte-specific deletion of autophagy-related 5 (Atg5) leads to glomerulopathy in aging mice and this was associated with ER stress, podocyte loss, proteinuria and glomerulosclerosis [143]. mTOR closely regulates autophagy, further supporting the tight interconnections among ER stress, mTOR and autophagy pathways $[159,160]$.

\section{Modulation of ER Stress}

A number of therapeutic strategies designed to modulate ER stress have been employed in kidney diseases. Preconditioning with low doses of ER stress inducers TM and thapsigargin (TG) is protective 
in mesangioproliferative glomerulonephritis, Heymann's nephritis and ischemia-reperfusion [161-163]. Preconditioning has not been studied in diabetic kidney disease, perhaps due to its chronic nature. However, in a model of diabetic retinopathy, the salutary effect of ER stress preconditioning in retinal endothelial cells is dependent on XBP-1 expression [164].

ER chaperones have been used therapeutically to promote protein folding and to reduce protein aggregation in the ER [165-167]. Tauroursodeoxycholic acid (taurine conjugate form of ursodeoxycholic acid, TUDCA) is a chemical chaperone that has been used in traditional Chinese medicine for a number of indications [168]. In murine podocytes TUDCA reduces AGE-induced expression of GRP78/BiP and podocyte apoptosis [85]. TUDCA restores defective autophagy and attenuates albuminuria and histopathological changes in diabetic mice, though these changes were associated with mild improvements in glucoses [169]. TUDCA also reduces inflammasome activation (suppression of caspase- 1 activation, IL-1 $\beta$ and IL-18 maturation) in a murine model of DKD [127]. In a clinical study 4 weeks of TUDCA improves hepatic and muscle insulin sensitivity and signaling but did not change markers of ER stress in muscle or adipose tissue [170]. Renal effects were not studied.

In a rat model of diabetes 4-phenyl butyric acid (4-PBA, $1 \mathrm{mg} / \mathrm{kg}$ ), an ER chaperone, attenuates manifestations of diabetic nephropathy including markers of renal oxidative stress such as NADPH oxidase activity, however the investigators only assessed one marker of ER stress (IRE1 $\alpha$ ) and 4-PBA treatment was associated with improved glycemic control and markers of renal function (BUN and creatinine) were unchanged [171]. In STZ-treated rats 4-PBA improves renal hypertrophy, hyperglycemia, urinary protein excretion and mesangial matrix expansion, however these changes were not associated with improvements in serum creatinine [172]. Nephrin is a large podocyte transmembrane protein that plays a key role in slit diaphragm integrity. Nephrin mutations, which cause congenital nephrosis can trigger the UPR, and 4-PBA facilitates plasma membrane expression of some nephrin mutants [173]. Indeed hyperactivation of mTORC1 (in diabetic nephropathy) is associated with ER stress and mislocalization of nephrin in podocytes. 4-PBA treatment of these mice significantly reduces GRP78/BiP expression and prevents podocyte loss, but does not normalize nephrin membrane localization or proteinuria [138]. In renal tubular epithelial cells 4-PBA decreases expression of GRP78/BIP, receptors for AGE (RAGE) and reduces premature senescence in cells pretreated with AGEs [174]. These studies demonstrate that ER chaperones modulate DKD, but it is unclear if their positive effects are related to improvements in glycemic control or direct modulation of ER stress in the kidney. However, they are encouraging and supportive of future human clinical studies in diabetic nephropathy.

Glucagon-like peptide-1 (Glp-1) is a metabolic hormone (incretin) secreted by intestinal cells. Liraglutide is a Glp-1 agonist used for the treatment of Type 2 diabetes and obesity. Liraglutide reduces ER stress in diabetic models of cardiomyopathy and pancreatic $\beta$-cell loss [175-177]. Additionally liraglutide is protective in diabetic kidney disease, though it is unclear if it modulates the UPR in the kidney [178,179]. Erlotinib, an epidermal growth factor receptor inhibitor slows the progression of murine diabetic nephropathy and this is associated with lower tubular and glomerular CHOP and lower glomerular GRP78/BiP and PERK expression. The downregulation in ER stress markers was associated with increased expression of key autophagy associated proteins including Atg12, beclin and LC3-II in renal glomeruli and tubules [180]. 
The XBP-1 arm of the ER stress response is generally cytoprotective, thus generalized downregulation of ER stress may not positively affect the progression of DKD. Strategies that augment XBP-1 activity may improve glycemic control and microvascular complications of diabetes [60]. A number of groups have synthesized small molecules that block IRE-1 $\alpha$ activity and splicing of XBP-1 [181-185] for use in multiple myeloma and chronic lymphocytic leukemia, however their effect on diabetic nephropathy is unpredictable. Rapamycin (an mTOR inhibitor) may also selectively inhibit the IRE1 $\alpha$ pathway [186] and rapamycin has been successfully used in rodent models of diabetic kidney disease [187-191]. However, rapamycin's impact on the UPR has not been thoroughly evaluated, and its known effects of new-onset diabetes after transplantation (NODAT) and proteinuria may preclude its use in diabetics [192].

BiP inducer X (1-(3,4-dihydroxyohenyl)-2-thiocyanate-ethanone, BIX) is a small molecule GRP78/BiP inducer that also increases GRP94, calreticulin, and CHOP [193]. BIX activates the UPR selectively through ATF6, up-regulates renal GRP78/BiP expression and ameliorates renal ischemia-reperfusion injury [194]. Salubrinal, an inhibitor of eIF2 $\alpha$ phosphatases, was discovered in a screen for drugs that prevent ER stress-induced apoptosis. Phosphorylation of eIF2 $\alpha$ reduces protein synthesis and salubrinal protects cells from ER stress by maintaining high levels of phosphorylated eIF2 $\alpha$ [195]. In podocytes salubrinal restores defective autophagy and podocin expression [169], though in cisplatin-induced nephrotoxicity, salubrinal enhances oxidative stress and renal injury [196]. Although BIX and salubrinal may provide benefit, their effects in DKD are unknown. Similar approaches to limit protein synthesis in the kidney may be theoretically beneficial in DKD [84]. RIDD activation reduces the toxicity of acetaminophen overdose by degrading key hepatic cytochrome enzymes which covert acetaminophen to its toxic metabolites [197]. The relevance of RIDD activity in the kidney is still not clear, but augmentation of RIDD activity may provide a novel therapeutic approach.

Angiotensin converting enzyme inhibitors (ACE I) and angiotensin receptor blockers (ARB) are currently used to slow the progression of DKD. In murine STZ-induced diabetes high dose irbesartan (an ARB) reduces ER stress and apoptosis in tubules [198]. In rat STZ-induced diabetes perindopril (an ACE I) reduces markers of ER stress and apoptosis in the tubulo-interstitium [199]. In contrast in rodent diabetic kidney disease low dose irbesartan reduces albuminuria and inflammation, but does not reduce ER stress (calnexin and GRP78/BiP staining) [200]. Valsartan (an ARB) and aliskiren (direct renin inhibitor) also reduce $\mathrm{CHOP}$ and XBP-1 expression in rodent diabetic kidneys [201]. Thus the beneficial effects of renin-angiotensin system blockade, may be in part related to modulation of ER stress.

Febuxostat is a non-purine inhibitor of xanthine oxidase and is used therapeutically for gout and hyperuricemia. In a rat ischemia-reperfusion model febuxostat improves renal function, inflammation and apoptosis by inhibiting oxidative and ER stress [202]. In rat STZ-induced diabetes febuxostat reduces albuminuria, glomerular macrophage infiltration and inflammation [203], though its effects on ER stress have not been reported. Recently Wang and colleagues demonstrated in male obese Zucker rats that low dose acetaminophen reduces ER-stress signaling, tubular and glomerular apoptosis and albuminuria [204]. Thus, some currently approved and widely-used medications such as ACE I, ARBs, febuxostat, liraglutide, rapamycin and low dose acetaminophen may modulate the UPR and attenuate the progression of DKD. However these agents may reduce renal injury and indirectly ER stress, thus further studies are indicated to evaluate their precise effects on ER stress pathways in the diabetic kidney. 


\section{Problems with UPR/ER Stress Studies in the Kidney}

Many studies are based on the assumption that high levels of ER stress-related molecules denote active ER stress. However Rutkowski and Hedge have postulated that changes in ER stress-associated molecules may represent homeostatic fluctuations in the ER in response to rapidly changing environmental conditions [4]. Moreover, some studies investigate only one or two ER stress-related molecules and assume that the UPR is activated. In these studies more thorough investigative methods are indicated [205]. Our understanding of the UPR is also hindered by the difficulty in blocking or activating a single arm of the UPR, as the pathways are highly interconnected among themselves and with other downstream signaling cascades. It is also clear that ER stress is neither good nor bad for the kidney; one must be careful not to correlate downregulation of ER stress (by one or two ER stress markers) as beneficial, especially given the cyto-protective effects of XBP-1.

\section{Future Directions and Conclusions}

The UPR is very dynamic with a wide range of inputs and outputs that enable the cell to respond to a number of diverse stimuli and cellular conditions. ER stress is activated in the diabetic kidney and the UPR restores normal organ function in aberrant physiological conditions. However, chronic activation of these pathways likely contributes to chronic renal injury, inflammation and the progression of chronic kidney disease. Many questions remain regarding which renal cells are most affected by ER stress and whether activation of one pathway constitutes the ER stress response, or must all three arms of the UPR be activated? Moreover, few studies evaluate the temporal patterns of ER stress activation and it is likely that timing will have a profound effect on outcomes. The development of specific ER stress modulators that modify individual arms of the UPR will provide therapeutic strategies to treat the development and progression of DKD. Additionally, the ability to carefully amplify or reduce UPR activation may also be efficacious. Furthermore, focused studies investigating ER stress in humans or humanized rodent models will further our understanding of the UPR in the diabetic kidney.

\section{Acknowledgments}

These studies were performed with the support of the Department of Veterans Affairs Merit Award.

\section{Conflicts of Interest}

The author declares no conflict of interest.

\section{References}

1. Jha, V.; Garcia-Garcia, G.; Iseki, K.; Li, Z.; Naicker, S.; Plattner, B.; Saran, R.; Wang, A.Y.; Yang, C.W. Chronic kidney disease: Global dimension and perspectives. Lancet 2013, 382, 260-272.

2. Gething, M.J.; McCammon, K.; Sambrook, J. Expression of wild-type and mutant forms of influenza hemagglutinin: The role of folding in intracellular transport. Cell 1986, 46, 939-950. 
3. Kozutsumi, Y.; Segal, M.; Normington, K.; Gething, M.J.; Sambrook, J. The presence of malfolded proteins in the endoplasmic reticulum signals the induction of glucose-regulated proteins. Nature 1988, 332, 462-464.

4. Rutkowski, D.T.; Hegde, R.S. Regulation of basal cellular physiology by the homeostatic unfolded protein response. J. Cell Biol. 2010, 189, 783-794.

5. Arensdorf, A.M.; Diedrichs, D.; Rutkowski, D.T. Regulation of the transcriptome by ER stress: Non-canonical mechanisms and physiological consequences. Front. Genet. 2013, 4, doi:10.3389/fgene.2013.00256.

6. Bettigole, S.E.; Glimcher, L.H. Endoplasmic reticulum stress in immunity. Annu. Rev. Immunol. 2014, 8, 663-674.

7. Bartoszewska, S.; Kochan, K.; Madanecki, P.; Piotrowski, A.; Ochocka, R.; Collawn, J.F.; Bartoszewski, R. Regulation of the unfolded protein response by microRNAs. Cell Mol. Biol. Lett. 2013, 18, 555-578.

8. Maurel, M.; Chevet, E. Endoplasmic reticulum stress signaling: The microRNA connection. Am. J. Physiol. Cell Physiol. 2013, 304, C1117-C1126.

9. Maurel, M.; Dejeans, N.; Taouji, S.; Chevet, E.; Grosset, C.F. MicroRNA-1291-mediated silencing of IRE1alpha enhances Glypican-3 expression. RNA 2013, 19, 778-788.

10. Matsumoto, M.; Minami, M.; Takeda, K.; Sakao, Y.; Akira, S. Ectopic expression of CHOP (GADD153) induces apoptosis in M1 myeloblastic leukemia cells. FEBS Lett. 1996, 395, 143-147.

11. Nakagawa, T.; Zhu, H.; Morishima, N.; Li, E.; Xu, J.; Yankner, B.A.; Yuan, J. Caspase-12 mediates endoplasmic-reticulum-specific apoptosis and cytotoxicity by amyloid-beta. Nature 2000, 403, 98-103.

12. Xu, C.; Bailly-Maitre, B.; Reed, J.C. Endoplasmic reticulum stress: Cell life and death decisions. J. Clin. Investig. 2005, 115, 2656-2664.

13. Szegezdi, E.; Logue, S.E.; Gorman, A.M.; Samali, A. Mediators of endoplasmic reticulum stress-induced apoptosis. EMBO Rep. 2006, 7, 880-885.

14. Kim, R.; Emi, M.; Tanabe, K.; Murakami, S. Role of the unfolded protein response in cell death. Apoptosis 2006, 11, 5-13.

15. Bertolotti, A.; Zhang, Y.; Hendershot, L.M.; Harding, H.P.; Ron, D. Dynamic interaction of BiP and ER stress transducers in the unfolded-protein response. Nat. Cell Biol. 2000, 2, 326-332.

16. Shen, J.; Chen, X.; Hendershot, L.; Prywes, R. ER stress regulation of atf6 localization by dissociation of BiP/GRP78 binding and unmasking of Golgi localization signals. Dev. Cell 2002, 3, 99-111.

17. Ron, D.; Walter, P. Signal integration in the endoplasmic reticulum unfolded protein response. Nat. Rev. Mol. Cell Biol. 2007, 8, 519-529.

18. Pincus, D.; Chevalier, M.W.; Aragon, T.; van Anken, E.; Vidal, S.E.; el-Samad, H.; Walter, P. BiP binding to the ER-stress sensor IRE1 tunes the homeostatic behavior of the unfolded protein response. PLoS Biol. 2010, 8, e1000415.

19. Harding, H.P.; Zhang, Y.; Bertolotti, A.; Zeng, H.; Ron, D. Perk is essential for translational regulation and cell survival during the unfolded protein response. Mol. Cell 2000, 5, 897-904. 
20. Ventoso, I.; Kochetov, A.; Montaner, D.; Dopazo, J.; Santoyo, J. Extensive translatome remodeling during ER stress response in mammalian cells. PLOS ONE 2012, 7, e35915.

21. Cybulsky, A.V.; Takano, T.; Papillon, J.; Bijian, K. Role of the endoplasmic reticulum unfolded protein response in glomerular epithelial cell injury. J. Biol. Chem. 2005, 280, 24396-24403.

22. Fawcett, T.W.; Martindale, J.L.; Guyton, K.Z.; Hai, T.; Holbrook, N.J. Complexes containing activating transcription factor (ATF)/camp-responsive-element-binding protein (CREB) interact with the CCAAT/enhancer-binding protein (c/EBP)-ATF composite site to regulate GADD153 expression during the stress response. Biochem. J. 1999, 339, 135-141.

23. Harding, H.P.; Novoa, I.; Zhang, Y.; Zeng, H.; Wek, R.; Schapira, M.; Ron, D. Regulated translation initiation controls stress-induced gene expression in mammalian cells. Mol. Cell 2000, 6, 1099-1108.

24. Ma, Y.; Brewer, J.W.; Diehl, J.A.; Hendershot, L.M. Two distinct stress signaling pathways converge upon the CHOP promoter during the mammalian unfolded protein response. J. Mol. Biol. 2002, 318, 1351-1365.

25. Ma, Y.; Hendershot, L.M. Delineation of a negative feedback regulatory loop that controls protein translation during endoplasmic reticulum stress. J. Biol. Chem. 2003, 278, 34864-34873.

26. Pereira, E.R.; Frudd, K.; Awad, W.; Hendershot, L.M. Endoplasmic reticulum (ER) stress and hypoxia response pathways interact to potentiate hypoxia-inducible factor 1 (HIF-1) transcriptional activity on targets like vascular endothelial growth factor (VEGF). J. Biol. Chem. 2014, 289, 3352-3364.

27. Ohoka, N.; Yoshii, S.; Hattori, T.; Onozaki, K.; Hayashi, H. TRB3, a novel ER stress-inducible gene, is induced via ATF4-CHOP pathway and is involved in cell death. EMBO J. 2005, 24, 1243-1255.

28. Saito, A.; Ochiai, K.; Kondo, S.; Tsumagari, K.; Murakami, T.; Cavener, D.R.; Imaizumi, K. Endoplasmic reticulum stress response mediated by the PERK-eIF2(alpha)-ATF4 pathway is involved in osteoblast differentiation induced by BMP2. J. Biol. Chem. 2011, 286, 4809-4818.

29. Harding, H.P.; Zhang, Y.; Zeng, H.; Novoa, I.; Lu, P.D.; Calfon, M.; Sadri, N.; Yun, C.; Popko, B.; Paules, R.; et al. An integrated stress response regulates amino acid metabolism and resistance to oxidative stress. Mol. Cell 2003, 11, 619-633.

30. Ameri, K.; Harris, A.L. Activating transcription factor 4. Int. J. Biochem. Cell Biol. 2008, 40, $14-21$.

31. Mori, K. Signalling pathways in the unfolded protein response: Development from yeast to mammals. J. Biochem. 2009, 146, 743-750.

32. Cox, J.S.; Shamu, C.E.; Walter, P. Transcriptional induction of genes encoding endoplasmic reticulum resident proteins requires a transmembrane protein kinase. Cell 1993, 73, 1197-1206.

33. Mori, K.; Ma, W.; Gething, M.J.; Sambrook, J. A transmembrane protein with a cdc2+/CDC28-related kinase activity is required for signaling from the ER to the nucleus. Cell 1993, 74, 743-756.

34. Oikawa, D.; Kimata, Y.; Kohno, K.; Iwawaki, T. Activation of mammalian irelalpha upon ER stress depends on dissociation of BiP rather than on direct interaction with unfolded proteins. Exp. Cell Res. 2009, 315, 2496-2504. 
35. Calfon, M.; Zeng, H.; Urano, F.; Till, J.H.; Hubbard, S.R.; Harding, H.P.; Clark, S.G.; Ron, D. IRE1 couples endoplasmic reticulum load to secretory capacity by processing the XBP-1 mRNA. Nature 2002, 415, 92-96.

36. Yoshida, H.; Matsui, T.; Yamamoto, A.; Okada, T.; Mori, K. XBP1 mRNA is induced by ATF6 and spliced by IRE1 in response to ER stress to produce a highly active transcription factor. Cell 2001, 107, 881-891.

37. Lee, A.H.; Iwakoshi, N.N.; Glimcher, L.H. XBP-1 regulates a subset of endoplasmic reticulum resident chaperone genes in the unfolded protein response. Mol. Cell Biol. 2003, 23, 7448-7459.

38. Acosta-Alvear, D.; Zhou, Y.; Blais, A.; Tsikitis, M.; Lents, N.H.; Arias, C.; Lennon, C.J.; Kluger, Y.; Dynlacht, B.D. XBP1 controls diverse cell type- and condition-specific transcriptional regulatory networks. Mol. Cell 2007, 27, 53-66.

39. Yoshida, H.; Oku, M.; Suzuki, M.; Mori, K. pXBP1(U) encoded in XBP1 pre-mRNA negatively regulates unfolded protein response activator $\mathrm{pXBP} 1(\mathrm{~S})$ in mammalian ER stress response. J. Cell Biol. 2006, 172, 565-575.

40. Tirosh, B.; Iwakoshi, N.N.; Glimcher, L.H.; Ploegh, H.L. Rapid turnover of unspliced XBP-1 as a factor that modulates the unfolded protein response. J. Biol. Chem. 2006, 281, 5852-5860.

41. Hetz, C.; Glimcher, L.H. Fine-tuning of the unfolded protein response: Assembling the IRE1alpha interactome. Mol. Cell 2009, 35, 551-561.

42. Urano, F.; Wang, X.; Bertolotti, A.; Zhang, Y.; Chung, P.; Harding, H.P.; Ron, D. Coupling of stress in the ER to activation of JNK protein kinases by transmembrane protein kinase IRE1. Science 2000, 287, 664-666.

43. Kim, I.; Shu, C.W.; Xu, W.; Shiau, C.W.; Grant, D.; Vasile, S.; Cosford, N.D.; Reed, J.C. Chemical biology investigation of cell death pathways activated by endoplasmic reticulum stress reveals cytoprotective modulators of ASK1. J. Biol. Chem. 2009, 284, 1593-1603.

44. Ogata, M.; Hino, S.; Saito, A.; Morikawa, K.; Kondo, S.; Kanemoto, S.; Murakami, T.; Taniguchi, M.; Tanii, I.; Yoshinaga, K.; et al. Autophagy is activated for cell survival after endoplasmic reticulum stress. Mol. Cell Biol. 2006, 26, 9220-9231.

45. Bernales, S.; McDonald, K.L.; Walter, P. Autophagy counterbalances endoplasmic reticulum expansion during the unfolded protein response. PLoS Biol. 2006, 4, e423.

46. Yorimitsu, T.; Nair, U.; Yang, Z.; Klionsky, D.J. Endoplasmic reticulum stress triggers autophagy. J. Biol. Chem. 2006, 281, 30299-30304.

47. Iwakoshi, N.N.; Lee, A.H.; Glimcher, L.H. The X-box binding protein-1 transcription factor is required for plasma cell differentiation and the unfolded protein response. Immunol. Rev. 2003, 194, 29-38.

48. Reimold, A.M.; Etkin, A.; Clauss, I.; Perkins, A.; Friend, D.S.; Zhang, J.; Horton, H.F.; Scott, A.; Orkin, S.H.; Byrne, M.C.; et al. An essential role in liver development for transcription factor XBP-1. Genes Dev. 2000, 14, 152-157.

49. Reimold, A.M.; Iwakoshi, N.N.; Manis, J.; Vallabhajosyula, P.; Szomolanyi-Tsuda, E.; Gravallese, E.M.; Friend, D.; Grusby, M.J.; Alt, F.; Glimcher, L.H. Plasma cell differentiation requires the transcription factor XBP-1. Nature 2001, 412, 300-307. 
50. Iwakoshi, N.N.; Lee, A.H.; Vallabhajosyula, P.; Otipoby, K.L.; Rajewsky, K.; Glimcher, L.H. Plasma cell differentiation and the unfolded protein response intersect at the transcription factor XBP-1. Nat. Immunol. 2003, 4, 321-329.

51. Iwakoshi, N.N.; Pypaert, M.; Glimcher, L.H. The transcription factor XBP-1 is essential for the development and survival of dendritic cells. J. Exp. Med. 2007, 204, 2267-2275.

52. Osorio, F.; Tavernier, S.J.; Hoffmann, E.; Saeys, Y.; Martens, L.; Vetters, J.; Delrue, I.; de Rycke, R.; Parthoens, E.; Pouliot, P.; et al. The unfolded-protein-response sensor IRE-1alpha regulates the function of CD8alpha+ dendritic cells. Nat. Immunol. 2014, 15, 248-257.

53. Kamimura, D.; Bevan, M.J. Endoplasmic reticulum stress regulator XBP-1 contributes to effector CD8+ T cell differentiation during acute infection. J. Immunol. 2008, 181, 5433-5441.

54. Lin, J.H.; Li, H.; Yasumura, D.; Cohen, H.R.; Zhang, C.; Panning, B.; Shokat, K.M.; Lavail, M.M.; Walter, P. IRE1 signaling affects cell fate during the unfolded protein response. Science 2007, 318, 944-949.

55. Lisbona, F.; Rojas-Rivera, D.; Thielen, P.; Zamorano, S.; Todd, D.; Martinon, F.; Glavic, A.; Kress, C.; Lin, J.H.; Walter, P.; et al. Bax inhibitor-1 is a negative regulator of the ER stress sensor IRE1alpha. Mol. Cell 2009, 33, 679-691.

56. Shaffer, A.L.; Shapiro-Shelef, M.; Iwakoshi, N.N.; Lee, A.H.; Qian, S.B.; Zhao, H.; Yu, X.; Yang, L.; Tan, B.K.; Rosenwald, A.; et al. XBP1, downstream of Blimp-1, expands the secretory apparatus and other organelles, and increases protein synthesis in plasma cell differentiation. Immunity 2004, 21, 81-93.

57. Liu, Y.; Adachi, M.; Zhao, S.; Hareyama, M.; Koong, A.C.; Luo, D.; Rando, T.A.; Imai, K.; Shinomura, Y. Preventing oxidative stress: A new role for XBP1. Cell Death Differ. 2009, 16, 847-857.

58. Ghosh, R.; Lipson, K.L.; Sargent, K.E.; Mercurio, A.M.; Hunt, J.S.; Ron, D.; Urano, F. Transcriptional regulation of VEGF-A by the unfolded protein response pathway. PLOS ONE 2010, 5, e9575.

59. Karali, E.; Bellou, S.; Stellas, D.; Klinakis, A.; Murphy, C.; Fotsis, T. VEGF signals through ATF6 and PERK to promote endothelial cell survival and angiogenesis in the absence of ER stress. Mol. Cell 2014, 54, 559-572.

60. Zhou, Y.; Lee, J.; Reno, C.M.; Sun, C.; Park, S.W.; Chung, J.; Lee, J.; Fisher, S.J.; White, M.F.; Biddinger, S.B.; et al. Regulation of glucose homeostasis through a XBP-1-foxO1 interaction. Nat. Med. 2011, 17, 356-365.

61. Lee, J.; Sun, C.; Zhou, Y.; Lee, J.; Gokalp, D.; Herrema, H.; Park, S.W.; Davis, R.J.; Ozcan, U. p38 MAPK-mediated regulation of Xbp1s is crucial for glucose homeostasis. Nat. Med. 2011, 17, 1251-1260.

62. Wang, Z.V.; Deng, Y.; Gao, N.; Pedrozo, Z.; Li, D.L.; Morales, C.R.; Criollo, A.; Luo, X.; Tan, W.; Jiang, N.; et al. Spliced X-box binding protein 1 couples the unfolded protein response to hexosamine biosynthetic pathway. Cell 2014, 156, 1179-1192.

63. Taylor, R.C.; Dillin, A. XBP-1 is a cell-nonautonomous regulator of stress resistance and longevity. Cell 2013, 153, 1435-1447. 
64. Chen, X.; Iliopoulos, D.; Zhang, Q.; Tang, Q.; Greenblatt, M.B.; Hatziapostolou, M.; Lim, E.; Tam, W.L.; Ni, M.; Chen, Y.; et al. XBP1 promotes triple-negative breast cancer by controlling the HIF1alpha pathway. Nature 2014, 508, 103-107.

65. Hollien, J.; Weissman, J.S. Decay of endoplasmic reticulum-localized mRNAs during the unfolded protein response. Science 2006, 313, 104-107.

66. Han, D.; Lerner, A.G.; vande Walle, L.; Upton, J.P.; Xu, W.; Hagen, A.; Backes, B.J.; Oakes, S.A.; Papa, F.R. IRE1alpha kinase activation modes control alternate endoribonuclease outputs to determine divergent cell fates. Cell 2009, 138, 562-575.

67. Hollien, J.; Lin, J.H.; Li, H.; Stevens, N.; Walter, P.; Weissman, J.S. Regulated IRE1-dependent decay of messenger RNAs in mammalian cells. J. Cell Biol. 2009, 186, 323-331.

68. Upton, J.P.; Wang, L.; Han, D.; Wang, E.S.; Huskey, N.E.; Lim, L.; Truitt, M.; McManus, M.T.; Ruggero, D.; Goga, A.; et al. IRE1alpha cleaves select microRNAs during ER stress to derepress translation of proapoptotic caspase-2. Science 2012, 338, 818-822.

69. Lerner, A.G.; Upton, J.P.; Praveen, P.V.; Ghosh, R.; Nakagawa, Y.; Igbaria, A.; Shen, S.; Nguyen, V.; Backes, B.J.; Heiman, M.; et al. IRE1alpha induces thioredoxin-interacting protein to activate the NLRP3 inflammasome and promote programmed cell death under irremediable ER stress. Cell Metab. 2012, 16, 250-264.

70. Haze, K.; Yoshida, H.; Yanagi, H.; Yura, T.; Mori, K. Mammalian transcription factor ATF6 is synthesized as a transmembrane protein and activated by proteolysis in response to endoplasmic reticulum stress. Mol. Biol. Cell 1999, 10, 3787-3799.

71. Li, M.; Baumeister, P.; Roy, B.; Phan, T.; Foti, D.; Luo, S.; Lee, A.S. ATF6 as a transcription activator of the endoplasmic reticulum stress element: Thapsigargin stress-induced changes and synergistic interactions with NF-Y and YY1. Mol. Cell Biol. 2000, 20, 5096-5106.

72. Wu, J.; Rutkowski, D.T.; Dubois, M.; Swathirajan, J.; Saunders, T.; Wang, J.; Song, B.; Yau, G.D.; Kaufman, R.J. ATF6alpha optimizes long-term endoplasmic reticulum function to protect cells from chronic stress. Dev. Cell 2007, 13, 351-364.

73. Yamamoto, K.; Sato, T.; Matsui, T.; Sato, M.; Okada, T.; Yoshida, H.; Harada, A.; Mori, K. Transcriptional induction of mammalian ER quality control proteins is mediated by single or combined action of ATF6alpha and XBP1. Dev. Cell 2007, 13, 365-376.

74. Adachi, Y.; Yamamoto, K.; Okada, T.; Yoshida, H.; Harada, A.; Mori, K. ATF6 is a transcription factor specializing in the regulation of quality control proteins in the endoplasmic reticulum. Cell Struct. Funct. 2008, 33, 75-89.

75. Van Huizen, R.; Martindale, J.L.; Gorospe, M.; Holbrook, N.J. P58IPK, a novel endoplasmic reticulum stress-inducible protein and potential negative regulator of eIF2alpha signaling. J. Biol. Chem. 2003, 278, 15558-15564.

76. Belmont, P.J.; Chen, W.J.; San Pedro, M.N.; Thuerauf, D.J.; Gellings Lowe, N.; Gude, N.; Hilton, B.; Wolkowicz, R.; Sussman, M.A.; Glembotski, C.C. Roles for endoplasmic reticulum-associated degradation and the novel endoplasmic reticulum stress response gene Derlin-3 in the ischemic heart. Circ. Res. 2010, 106, 307-316.

77. Ye, J.; Rawson, R.B.; Komuro, R.; Chen, X.; Dave, U.P.; Prywes, R.; Brown, M.S.; Goldstein, J.L. ER stress induces cleavage of membrane-bound ATF6 by the same proteases that process SREBPS. Mol. Cell 2000, 6, 1355-1364. 
78. Pahl, H.L. Signal transduction from the endoplasmic reticulum to the cell nucleus. Physiol. Rev. 1999, 79, 683-701.

79. Shaffer, A.L.; Lin, K.I.; Kuo, T.C.; Yu, X.; Hurt, E.M.; Rosenwald, A.; Giltnane, J.M.; Yang, L.; Zhao, H.; Calame, K.; et al. Blimp-1 orchestrates plasma cell differentiation by extinguishing the mature B cell gene expression program. Immunity 2002, 17, 51-62.

80. Matsumoto, T.; Hess, S.; Kajiyama, H.; Sakairi, T.; Saleem, M.A.; Mathieson, P.W.; Nojima, Y.; Kopp, J.B. Proteomic analysis identifies insulin-like growth factor-binding protein-related protein-1 as a podocyte product. Am. J. Physiol. 2010, 299, F776-F784.

81. Erguler, K.; Pieri, M.; Deltas, C. A mathematical model of the unfolded protein stress response reveals the decision mechanism for recovery, adaptation and apoptosis. BMC Syst. Biol. 2013, 7, doi:10.1186/1752-0509-7-16.

82. Morse, E.; Schroth, J.; You, Y.H.; Pizzo, D.P.; Okada, S.; Ramachandrarao, S.; Vallon, V.; Sharma, K.; Cunard, R. TRB3 is stimulated in diabetic kidneys, regulated by the ER stress marker CHOP, and is a suppressor of podocyte MCP-1. Am. J. Physiol. 2010, 299, F965-F972.

83. Halterman, M.W.; Gill, M.; deJesus, C.; Ogihara, M.; Schor, N.F.; Federoff, H.J. The endoplasmic reticulum stress response factor $\mathrm{CHOP}-10$ protects against hypoxia-induced neuronal death. J. Biol. Chem. 2010, 285, 21329-21340.

84. Han, J.; Back, S.H.; Hur, J.; Lin, Y.H.; Gildersleeve, R.; Shan, J.; Yuan, C.L.; Krokowski, D.; Wang, S.; Hatzoglou, M.; et al. ER-stress-induced transcriptional regulation increases protein synthesis leading to cell death. Nat. Cell Biol. 2013, 15, 481-490.

85. Chen, Y.; Liu, C.P.; Xu, K.F.; Mao, X.D.; Lu, Y.B.; Fang, L.; Yang, J.W.; Liu, C. Effect of taurine-conjugated ursodeoxycholic acid on endoplasmic reticulum stress and apoptosis induced by advanced glycation end products in cultured mouse podocytes. Am. J. Nephrol. 2008, 28, 1014-1022.

86. Cao, Y.; Hao, Y.; Li, H.; Liu, Q.; Gao, F.; Liu, W.; Duan, H. Role of endoplasmic reticulum stress in apoptosis of differentiated mouse podocytes induced by high glucose. Int. J. Mol. Med. 2014, 33, 809-816.

87. Sieber, J.; Lindenmeyer, M.T.; Kampe, K.; Campbell, K.N.; Cohen, C.D.; Hopfer, H.; Mundel, P.; Jehle, A.W. Regulation of podocyte survival and endoplasmic reticulum stress by fatty acids. Am. J. Physiol. 2010, 299, F821-F829.

88. Lim, J.C.; Lim, S.K.; Han, H.J.; Park, S.H. Cannabinoid receptor 1 mediates palmitic acid-induced apoptosis via endoplasmic reticulum stress in human renal proximal tubular cells. $J$. Cell Physiol. 2010, 225, 654-663.

89. Zhao, S.; Zhu, L.; Duan, H.; Liu, S.; Liu, Q.; Liu, W.; Hao, J. PI3K/AKT pathway mediates high glucose-induced lipid accumulation in human renal proximal tubular cells via spliced XBP-1. J. Cell Biochem. 2012, 113, 3288-3298.

90. Shao, D.; Liu, J.; Ni, J.; Wang, Z.; Shen, Y.; Zhou, L.; Huang, Y.; Wang, J.; Xue, H.; Zhang, W.; et al. Suppression of XBP1s mediates high glucose-induced oxidative stress and extracellular matrix synthesis in renal mesangial cell and kidney of diabetic rats. PLOS ONE 2013, 8, e56124.

91. Muratsu-Ikeda, S.; Nangaku, M.; Ikeda, Y.; Tanaka, T.; Wada, T.; Inagi, R. Downregulation of miR-205 modulates cell susceptibility to oxidative and endoplasmic reticulum stresses in renal tubular cells. PLOS ONE 2012, 7, e41462. 
92. Nakajima, S.; Kato, H.; Gu, L.; Takahashi, S.; Johno, H.; Umezawa, K.; Kitamura, M. Pleiotropic potential of dehydroxymethylepoxyquinomicin for NF-kappaB suppression via reactive oxygen species and unfolded protein response. J. Immunol. 2013, 190, 6559-6569.

93. Harding, H.P.; Zeng, H.; Zhang, Y.; Jungries, R.; Chung, P.; Plesken, H.; Sabatini, D.D.; Ron, D. Diabetes mellitus and exocrine pancreatic dysfunction in perk $^{-/-}$mice reveals a role for translational control in secretory cell survival. Mol. Cell 2001, 7, 1153-1163.

94. Zhang, P.; McGrath, B.; Li, S.; Frank, A.; Zambito, F.; Reinert, J.; Gannon, M.; Ma, K.; McNaughton, K.; Cavener, D.R. The PERK eukaryotic initiation factor 2 alpha kinase is required for the development of the skeletal system, postnatal growth, and the function and viability of the pancreas. Mol. Cell Biol. 2002, 22, 3864-3874.

95. Scheuner, D.; Song, B.; McEwen, E.; Liu, C.; Laybutt, R.; Gillespie, P.; Saunders, T.; Bonner-Weir, S.; Kaufman, R.J. Translational control is required for the unfolded protein response and in vivo glucose homeostasis. Mol. Cell 2001, 7, 1165-1176.

96. Iwawaki, T.; Akai, R.; Kohno, K. IRE1alpha disruption causes histological abnormality of exocrine tissues, increase of blood glucose level, and decrease of serum immunoglobulin level. PLOS ONE 2010, 5, e13052.

97. Wang, H.; Kouri, G.; Wollheim, C.B. ER stress and SREBP-1 activation are implicated in beta-cell glucolipotoxicity. J. Cell Sci. 2005, 118, 3905-3915.

98. Karaskov, E.; Scott, C.; Zhang, L.; Teodoro, T.; Ravazzola, M.; Volchuk, A. Chronic palmitate but not oleate exposure induces endoplasmic reticulum stress, which may contribute to INS-1 pancreatic beta-cell apoptosis. Endocrinology 2006, 147, 3398-3407.

99. Laybutt, D.R.; Preston, A.M.; Akerfeldt, M.C.; Kench, J.G.; Busch, A.K.; Biankin, A.V.; Biden, T.J. Endoplasmic reticulum stress contributes to beta cell apoptosis in type 2 diabetes. Diabetologia 2007, 50, 752-763.

100. Oyadomari, S.; Koizumi, A.; Takeda, K.; Gotoh, T.; Akira, S.; Araki, E.; Mori, M. Targeted disruption of the CHOP gene delays endoplasmic reticulum stress-mediated diabetes. J. Clin. Investig. 2002, 109, 525-532.

101. Yoshioka, M.; Kayo, T.; Ikeda, T.; Koizumi, A. A novel locus, Mody4, distal to D7Mit189 on chromosome 7 determines early-onset NIDDM in nonobese C57BL/6 (Akita) mutant mice. Diabetes 1997, 46, 887-894.

102. Wang, J.; Takeuchi, T.; Tanaka, S.; Kubo, S.K.; Kayo, T.; Lu, D.; Takata, K.; Koizumi, A.; Izumi, T. A mutation in the insulin 2 gene induces diabetes with severe pancreatic beta-cell dysfunction in the Mody mouse. J. Clin. Investig. 1999, 103, 27-37.

103. Breyer, M.D.; Bottinger, E.; Brosius, F.C., 3rd; Coffman, T.M.; Harris, R.C.; Heilig, C.W.; Sharma, K. Mouse models of diabetic nephropathy. J. Am. Soc. Nephrol. 2005, 16, 27-45.

104. Kimura, K.; Jin, H.; Ogawa, M.; Aoe, T. Dysfunction of the ER chaperone BIP accelerates the renal tubular injury. Biochem. Biophys. Res. Commun. 2008, 366, 1048-1053.

105. Liu, G.; Sun, Y.; Li, Z.; Song, T.; Wang, H.; Zhang, Y.; Ge, Z. Apoptosis induced by endoplasmic reticulum stress involved in diabetic kidney disease. Biochem. Biophys. Res. Commun. 2008, 370, 651-656. 
106. Wu, J.; Zhang, R.; Torreggiani, M.; Ting, A.; Xiong, H.; Striker, G.E.; Vlassara, H.; Zheng, F. Induction of diabetes in aged C57B6 mice results in severe nephropathy: An association with oxidative stress, endoplasmic reticulum stress, and inflammation. Am. J. Patholol. 2010, 176, 2163-2176.

107. Borsting, E.; Patel, S.V.; Decleves, A.E.; Lee, S.J.; Rahman, Q.M.; Akira, S.; Satriano, J.; Sharma, K.; Vallon, V.; Cunard, R. Tribbles homolog 3 attenuates mammalian target of rapamycin complex-2 signaling and inflammation in the diabetic kidney. J. Am. Soc. Nephrol. 2014, 25, 2067-2078.

108. Chen, J.; Guo, Y.; Zeng, W.; Huang, L.; Pang, Q.; Nie, L.; Mu, J.; Yuan, F.; Feng, B. ER stress triggers MCP-1 expression through SET7/9-induced histone methylation in the kidneys of $d b / d b$ mice. Am. J. physiol. 2014, 306, F916-F925.

109. Sims-Robinson, C.; Zhao, S.; Hur, J.; Feldman, E.L. Central nervous system endoplasmic reticulum stress in a murine model of type 2 diabetes. Diabetologia 2012, 55, 2276-2284.

110. Lindenmeyer, M.T.; Rastaldi, M.P.; Ikehata, M.; Neusser, M.A.; Kretzler, M.; Cohen, C.D.; Schlondorff, D. Proteinuria and hyperglycemia induce endoplasmic reticulum stress. J. Am. Soc. Nephrol. 2008, 19, 2225-2236.

111. Fougeray, S.; Bouvier, N.; Beaune, P.; Legendre, C.; Anglicheau, D.; Thervet, E.; Pallet, N. Metabolic stress promotes renal tubular inflammation by triggering the unfolded protein response. Cell Death Dis. 2011, 2, e143.

112. Delepine, M.; Nicolino, M.; Barrett, T.; Golamaully, M.; Lathrop, G.M.; Julier, C. EIF2AK3, encoding translation initiation factor 2-alpha kinase 3, is mutated in patients with Wolcott-Rallison syndrome. Nat. Genet. 2000, 25, 406-409.

113. Iyer, S.; Korada, M.; Rainbow, L.; Kirk, J.; Brown, R.M.; Shaw, N.; Barrett, T.G. Wolcott-Rallison syndrome: A clinical and genetic study of three children, novel mutation in EIF2AK3 and a review of the literature. Acta Paediatr. 2004, 93, 1195-1201.

114. Bin-Abbas, B.; al-Mulhim, A.; al-Ashwal, A. Wolcott-Rallison syndrome in two siblings with isolated central hypothyroidism. Am. J. Med. Genet. 2002, 111, 187-190.

115. Zhang, K.; Kaufman, R.J. From endoplasmic-reticulum stress to the inflammatory response. Nature 2008, 454, 455-462.

116. Hotamisligil, G.S. Endoplasmic reticulum stress and the inflammatory basis of metabolic disease. Cell 2010, 140, 900-917.

117. Garcia-Garcia, P.M.; Getino-Melian, M.A.; Dominguez-Pimentel, V.; Navarro-Gonzalez, J.F. Inflammation in diabetic kidney disease. World J. Diabetes 2014, 5, 431-443.

118. Jiang, H.Y.; Wek, S.A.; McGrath, B.C.; Scheuner, D.; Kaufman, R.J.; Cavener, D.R.; Wek, R.C. Phosphorylation of the alpha subunit of eukaryotic initiation factor 2 is required for activation of NF-kappaB in response to diverse cellular stresses. Mol. Cell Biol. 2003, 23, 5651-5663.

119. Deng, J.; Lu, P.D.; Zhang, Y.; Scheuner, D.; Kaufman, R.J.; Sonenberg, N.; Harding, H.P.; Ron, D. Translational repression mediates activation of nuclear factor kappa B by phosphorylated translation initiation factor 2. Mol. Cell Biol. 2004, 24, 10161-10168.

120. Kaneko, M.; Niinuma, Y.; Nomura, Y. Activation signal of nuclear factor-kappa B in response to endoplasmic reticulum stress is transduced via IRE1 and tumor necrosis factor receptor-associated factor 2. Biol. Pharm. Bull. 2003, 26, 931-935. 
121. Hu, P.; Han, Z.; Couvillon, A.D.; Kaufman, R.J.; Exton, J.H. Autocrine tumor necrosis factor alpha links endoplasmic reticulum stress to the membrane death receptor pathway through IRE1alpha-mediated NF-kappaB activation and down-regulation of TRAF2 expression. Mol. Cell Biol. 2006, 26, 3071-3084.

122. Kitamura, M. Control of NF-kappaB and inflammation by the unfolded protein response. Int. Rev. Immunol. 2011, 30, 4-15.

123. Bertolotti, A.; Wang, X.; Novoa, I.; Jungreis, R.; Schlessinger, K.; Cho, J.H.; West, A.B.; Ron, D. Increased sensitivity to dextran sodium sulfate colitis in IRE1beta-deficient mice. $J$. Clin. Investig. 2001, 107, 585-593.

124. Janssens, S.; Pulendran, B.; Lambrecht, B.N. Emerging functions of the unfolded protein response in immunity. Nat. Immunol. 2014, 15, 910-919.

125. Martinon, F.; Burns, K.; Tschopp, J. The inflammasome: A molecular platform triggering activation of inflammatory caspases and processing of proIL-beta. Mol. Cell 2002, 10, 417-426.

126. Oslowski, C.M.; Hara, T.; O’Sullivan-Murphy, B.; Kanekura, K.; Lu, S.; Hara, M.; Ishigaki, S.; Zhu, L.J.; Hayashi, E.; Hui, S.T.; et al. Thioredoxin-interacting protein mediates ER stress-induced beta cell death through initiation of the inflammasome. Cell Metab. 2012, 16, 265-273.

127. Fang, L.; Xie, D.; Wu, X.; Cao, H.; Su, W.; Yang, J. Involvement of endoplasmic reticulum stress in albuminuria induced inflammasome activation in renal proximal tubular cells. PLoS ONE 2013, 8, e72344.

128. Esposito, V.; Grosjean, F.; Tan, J.; Huang, L.; Zhu, L.; Chen, J.; Xiong, H.; Striker, G.E.; Zheng, F. CHOP deficiency results in elevated lipopolysaccharide-induced inflammation and kidney injury. Am. J. Physiol. 2013, 304, F440-F450.

129. Brehm, M.A.; Shultz, L.D.; Greiner, D.L. Humanized mouse models to study human diseases. Curr. Opin. Endocrinol. Diabetes Obes. 2010, 17, 120-125.

130. Woo, C.W.; Cui, D.; Arellano, J.; Dorweiler, B.; Harding, H.; Fitzgerald, K.A.; Ron, D.; Tabas, I. Adaptive suppression of the ATF4-CHOP branch of the unfolded protein response by toll-like receptor signalling. Nat. Cell Biol. 2009, 11, 1473-1480.

131. Woo, C.W.; Kutzler, L.; Kimball, S.R.; Tabas, I. Toll-like receptor activation suppresses ER stress factor CHOP and translation inhibition through activation of eIF2B. Nat. Cell Biol. 2012, 14, 192-200.

132. Askew, D.S. Endoplasmic reticulum stress and fungal pathogenesis converge. Virulence 2014, 5, 331-333.

133. Seong, S.Y.; Matzinger, P. Hydrophobicity: An ancient damage-associated molecular pattern that initiates innate immune responses. Nat. Rev. 2004, 4, 469-478.

134. Garg, A.D.; Martin, S.; Golab, J.; Agostinis, P. Danger signalling during cancer cell death: Origins, plasticity and regulation. Cell Death Differ. 2014, 21, 26-38.

135. Garg, A.D.; Krysko, D.V.; Verfaillie, T.; Kaczmarek, A.; Ferreira, G.B.; Marysael, T.; Rubio, N.; Firczuk, M.; Mathieu, C.; Roebroek, A.J.; et al. A novel pathway combining calreticulin exposure and ATP secretion in immunogenic cancer cell death. EMBO J. 2012, 31, 1062-1079.

136. Krysko, D.V.; Garg, A.D.; Kaczmarek, A.; Krysko, O.; Agostinis, P.; Vandenabeele, P. Immunogenic cell death and damps in cancer therapy. Nat. Rev. Cancer 2012, 12, 860-875. 
137. Devaraj, S.; Tobias, P.; Kasinath, B.S.; Ramsamooj, R.; Afify, A.; Jialal, I. Knockout of toll-like receptor-2 attenuates both the proinflammatory state of diabetes and incipient diabetic nephropathy. Arterioscler. Thromb. Vasc. Biol. 2011, 31, 1796-1804.

138. Inoki, K.; Mori, H.; Wang, J.; Suzuki, T.; Hong, S.; Yoshida, S.; Blattner, S.M.; Ikenoue, T.; Ruegg, M.A.; Hall, M.N.; et al. mTORC1 activation in podocytes is a critical step in the development of diabetic nephropathy in mice. J. Clin. Investig. 2011, 121, 2181-2196.

139. Godel, M.; Hartleben, B.; Herbach, N.; Liu, S.; Zschiedrich, S.; Lu, S.; Debreczeni-Mor, A.; Lindenmeyer, M.T.; Rastaldi, M.P.; Hartleben, G.; et al. Role of mTOR in podocyte function and diabetic nephropathy in humans and mice. J. Clin. Investig. 2011, 121, 2197-2209.

140. Appenzeller-Herzog, C.; Hall, M.N. Bidirectional crosstalk between endoplasmic reticulum stress and mTOR signaling. Trends Cell Biol. 2012, 22, 274-282.

141. Huber, T.B.; Edelstein, C.L.; Hartleben, B.; Inoki, K.; Jiang, M.; Koya, D.; Kume, S.; Lieberthal, W.; Pallet, N.; Quiroga, A.; et al. Emerging role of autophagy in kidney function, diseases and aging. Autophagy 2012, 8, 1009-1031.

142. Tanaka, Y.; Kume, S.; Kitada, M.; Kanasaki, K.; Uzu, T.; Maegawa, H.; Koya, D. Autophagy as a therapeutic target in diabetic nephropathy. Exp. Diabetes Res. 2012, 2012, 628978.

143. Hartleben, B.; Godel, M.; Meyer-Schwesinger, C.; Liu, S.; Ulrich, T.; Kobler, S.; Wiech, T.; Grahammer, F.; Arnold, S.J.; Lindenmeyer, M.T.; et al. Autophagy influences glomerular disease susceptibility and maintains podocyte homeostasis in aging mice. J. Clin. Investig. 2010, 120, 1084-1096.

144. Ding, W.X.; Ni, H.M.; Gao, W.; Yoshimori, T.; Stolz, D.B.; Ron, D.; Yin, X.M. Linking of autophagy to ubiquitin-proteasome system is important for the regulation of endoplasmic reticulum stress and cell viability. Am. J. Pathol. 2007, 171, 513-524.

145. Fujita, E.; Kouroku, Y.; Isoai, A.; Kumagai, H.; Misutani, A.; Matsuda, C.; Hayashi, Y.K.; Momoi, T. Two endoplasmic reticulum-associated degradation (ERAD) systems for the novel variant of the mutant dysferlin: Ubiquitin/proteasome ERAD(I) and autophagy/lysosome ERAD(II). Hum. Mol. Genet. 2007, 16, 618-629.

146. Hoyer-Hansen, M.; Jaattela, M. Connecting endoplasmic reticulum stress to autophagy by unfolded protein response and calcium. Cell Death Differ. 2007, 14, 1576-1582.

147. Moretti, L.; Cha, Y.I.; Niermann, K.J.; Lu, B. Switch between apoptosis and autophagy: Radiation-induced endoplasmic reticulum stress? Cell Cycle 2007, 6, 793-798.

148. Hayashi-Nishino, M.; Fujita, N.; Noda, T.; Yamaguchi, A.; Yoshimori, T.; Yamamoto, A. A subdomain of the endoplasmic reticulum forms a cradle for autophagosome formation. Nat. Cell Biol. 2009, 11, 1433-1437.

149. Yla-Anttila, P.; Vihinen, H.; Jokitalo, E.; Eskelinen, E.L. 3D tomography reveals connections between the phagophore and endoplasmic reticulum. Autophagy 2009, 5, 1180-1185.

150. Verfaillie, T.; Salazar, M.; Velasco, G.; Agostinis, P. Linking ER stress to autophagy: Potential implications for cancer therapy. Int. J. Cell Biol. 2010, 2010, 930509.

151. Wei, Y.; Pattingre, S.; Sinha, S.; Bassik, M.; Levine, B. JNK1-mediated phosphorylation of Bcl-2 regulates starvation-induced autophagy. Mol. Cell 2008, 30, 678-688. 
152. Kouroku, Y.; Fujita, E.; Tanida, I.; Ueno, T.; Isoai, A.; Kumagai, H.; Ogawa, S.; Kaufman, R.J.; Kominami, E.; Momoi, T. ER stress (PERK/eIF2alpha phosphorylation) mediates the polyglutamine-induced LC3 conversion, an essential step for autophagy formation. Cell Death Differ. 2007, 14, 230-239.

153. Hetz, C.; Thielen, P.; Matus, S.; Nassif, M.; Court, F.; Kiffin, R.; Martinez, G.; Cuervo, A.M.; Brown, R.H.; Glimcher, L.H. XBP-1 deficiency in the nervous system protects against amyotrophic lateral sclerosis by increasing autophagy. Genes Dev. 2009, 23, 2294-2306.

154. Pehar, M.; Jonas, M.C.; Hare, T.M.; Puglielli, L. SLC33A1/AT-1 protein regulates the induction of autophagy downstream of IRE1/XBP1 pathway. J. Biol. Chem. 2012, 287, 29921-29930.

155. Pallet, N.; Bouvier, N.; Legendre, C.; Gilleron, J.; Codogno, P.; Beaune, P.; Thervet, E.; Anglicheau, D. Autophagy protects renal tubular cells against cyclosporine toxicity. Autophagy 2008, 4, 783-791.

156. Kawakami, T.; Inagi, R.; Takano, H.; Sato, S.; Ingelfinger, J.R.; Fujita, T.; Nangaku, M. Endoplasmic reticulum stress induces autophagy in renal proximal tubular cells. Nephrol. Dial. Transpl. 2009, 24, 2665-2672.

157. Asanuma, K.; Tanida, I.; Shirato, I.; Ueno, T.; Takahara, H.; Nishitani, T.; Kominami, E.; Tomino, Y. MAP-LC3, a promising autophagosomal marker, is processed during the differentiation and recovery of podocytes from PAN nephrosis. FASEB. J. 2003, 17, 1165-1167.

158. Wang, L.; Hong, Q.; Lv, Y.; Feng, Z.; Zhang, X.; Wu, L.; Cui, S.; Hou, K.; Su, H.; Huang, Z.; et al. Autophagy can repair endoplasmic reticulum stress damage of the passive Heymann nephritis model as revealed by proteomics analysis. J. Proteomics 2012, 75, 3866-3876.

159. Cybulsky, A.V. The intersecting roles of endoplasmic reticulum stress, ubiquitin-proteasome system, and autophagy in the pathogenesis of proteinuric kidney disease. Kidney Int. 2013, 84, 25-33.

160. Cunard, R. Mammalian tribbles homologs at the crossroads of endoplasmic reticulum stress and mammalian target of rapamycin pathways. Scientifica 2013, 2013, doi:10.1155/2013/750871.

161. Inagi, R.; Kumagai, T.; Nishi, H.; Kawakami, T.; Miyata, T.; Fujita, T.; Nangaku, M. Preconditioning with endoplasmic reticulum stress ameliorates mesangioproliferative glomerulonephritis. J. Am. Soc. Nephrol. 2008, 19, 915-922.

162. Cybulsky, A.V.; Takano, T.; Papillon, J.; Khadir, A.; Liu, J.; Peng, H. Complement C5b-9 membrane attack complex increases expression of endoplasmic reticulum stress proteins in glomerular epithelial cells. J. Biol. Chem. 2002, 277, 41342-41351.

163. Prachasilchai, W.; Sonoda, H.; Yokota-Ikeda, N.; Oshikawa, S.; Aikawa, C.; Uchida, K.; Ito, K.; Kudo, T.; Imaizumi, K.; Ikeda, M. A protective role of unfolded protein response in mouse ischemic acute kidney injury. Eur. J. Pharmacol. 2008, 592, 138-145.

164. Li, J.; Wang, J.J.; Zhang, S.X. Preconditioning with endoplasmic reticulum stress mitigates retinal endothelial inflammation via activation of X-box binding protein 1. J. Biol. Chem. 2011, 286, 4912-4921.

165. Ecroyd, H.; Carver, J.A. Unraveling the mysteries of protein folding and misfolding. IUBMB Life 2008, 60, 769-774.

166. Yang, D.S.; Yip, C.M.; Huang, T.H.; Chakrabartty, A.; Fraser, P.E. Manipulating the amyloid-beta aggregation pathway with chemical chaperones. J. Biol. Chem. 1999, 274, 32970-32974. 
167. Ma, Y.; Hendershot, L.M. ER chaperone functions during normal and stress conditions. J. Chem. Neuroanat. 2004, 28, 51-65.

168. Ozcan, U.; Yilmaz, E.; Ozcan, L.; Furuhashi, M.; Vaillancourt, E.; Smith, R.O.; Gorgun, C.Z.; Hotamisligil, G.S. Chemical chaperones reduce ER stress and restore glucose homeostasis in a mouse model of type 2 diabetes. Science 2006, 313, 1137-1140.

169. Fang, L.; Zhou, Y.; Cao, H.; Wen, P.; Jiang, L.; He, W.; Dai, C.; Yang, J. Autophagy attenuates diabetic glomerular damage through protection of hyperglycemia-induced podocyte injury. PLoS ONE 2013, 8, e60546.

170. Kars, M.; Yang, L.; Gregor, M.F.; Mohammed, B.S.; Pietka, T.A.; Finck, B.N.; Patterson, B.W.; Horton, J.D.; Mittendorfer, B.; Hotamisligil, G.S.; et al. Tauroursodeoxycholic acid may improve liver and muscle but not adipose tissue insulin sensitivity in obese men and women. Diabetes 2010, 59, 1899-1905.

171. Luo, Z.F.; Feng, B.; Mu, J.; Qi, W.; Zeng, W.; Guo, Y.H.; Pang, Q.; Ye, Z.L.; Liu, L.; Yuan, F.H. Effects of 4-phenylbutyric acid on the process and development of diabetic nephropathy induced in rats by streptozotocin: Regulation of endoplasmic reticulum stress-oxidative activation. Toxicol. Appl. Pharmacol. 2010, 246, 49-57.

172. Qi, W.; Mu, J.; Luo, Z.F.; Zeng, W.; Guo, Y.H.; Pang, Q.; Ye, Z.L.; Liu, L.; Yuan, F.H.; Feng, B. Attenuation of diabetic nephropathy in diabetes rats induced by streptozotocin by regulating the endoplasmic reticulum stress inflammatory response. Metabolism 2011, 60, 594-603.

173. Liu, X.L.; Done, S.C.; Yan, K.; Kilpelainen, P.; Pikkarainen, T.; Tryggvason, K. Defective trafficking of nephrin missense mutants rescued by a chemical chaperone. J. Am. Soc. Nephrol. 2004, 15, 1731-1738.

174. Liu, J.; Huang, K.; Cai, G.Y.; Chen, X.M.; Yang, J.R.; Lin, L.R.; Yang, J.; Huo, B.G.; Zhan, J.; He, Y.N. Receptor for advanced glycation end-products promotes premature senescence of proximal tubular epithelial cells via activation of endoplasmic reticulum stress-dependent p21 signaling. Cell Signal. 2014, 26, 110-121.

175. Liu, J.; Liu, Y.; Chen, L.; Wang, Y.; Li, J. Glucagon-like peptide-1 analog liraglutide protects against diabetic cardiomyopathy by the inhibition of the endoplasmic reticulum stress pathway. J. Diabetes Res. 2013, 2013, 630537.

176. Ji, Y.; Zhao, Z.; Cai, T.; Yang, P.; Cheng, M. Liraglutide alleviates diabetic cardiomyopathy by blocking CHOP-triggered apoptosis via the inhibition of the IRE-alpha pathway. Mol. Med. Rep. 2014, 9, 1254-1258.

177. Shimoda, M.; Kanda, Y.; Hamamoto, S.; Tawaramoto, K.; Hashiramoto, M.; Matsuki, M.; Kaku, K. The human glucagon-like peptide-1 analogue liraglutide preserves pancreatic beta cells via regulation of cell kinetics and suppression of oxidative and endoplasmic reticulum stress in a mouse model of diabetes. Diabetologia 2011, 54, 1098-1108.

178. Hendarto, H.; Inoguchi, T.; Maeda, Y.; Ikeda, N.; Zheng, J.; Takei, R.; Yokomizo, H.; Hirata, E.; Sonoda, N.; Takayanagi, R. Glp-1 analog liraglutide protects against oxidative stress and albuminuria in streptozotocin-induced diabetic rats via protein kinase a-mediated inhibition of renal NAD(P)H oxidases. Metabolism 2012, 61, 1422-1434.

179. Filippatos, T.D.; Elisaf, M.S. Effects of glucagon-like peptide-1 receptor agonists on renal function. World J. Diabetes 2013, 4, 190-201. 
180. Zhang, M.Z.; Wang, Y.; Paueksakon, P.; Harris, R.C. Epidermal growth factor receptor inhibition slows progression of diabetic nephropathy in association with a decrease in endoplasmic reticulum stress and an increase in autophagy. Diabetes 2014, 63, 2063-2072.

181. Volkmann, K.; Lucas, J.L.; Vuga, D.; Wang, X.; Brumm, D.; Stiles, C.; Kriebel, D.; der-Sarkissian, A.; Krishnan, K.; Schweitzer, C.; et al. Potent and selective inhibitors of the inositol-requiring enzyme 1 endoribonuclease. J. Biol. Chem. 2011, 286, 12743-12755.

182. Papandreou, I.; Denko, N.C.; Olson, M.; van Melckebeke, H.; Lust, S.; Tam, A.; Solow-Cordero, D.E.; Bouley, D.M.; Offner, F.; Niwa, M.; et al. Identification of an IRE1alpha endonuclease specific inhibitor with cytotoxic activity against human multiple myeloma. Blood 2011, 117, 1311-1314.

183. Cross, B.C.; Bond, P.J.; Sadowski, P.G.; Jha, B.K.; Zak, J.; Goodman, J.M.; Silverman, R.H.; Neubert, T.A.; Baxendale, I.R.; Ron, D.; et al. The molecular basis for selective inhibition of unconventional mRNA splicing by an IRE1-binding small molecule. Proc. Natl. Acad. Sci. USA 2012, 109, E869-E878.

184. Kriss, C.L.; Pinilla-Ibarz, J.A.; Mailloux, A.W.; Powers, J.J.; Tang, C.H.; Kang, C.W.; Zanesi, N.; Epling-Burnette, P.K.; Sotomayor, E.M.; Croce, C.M.; et al. Overexpression of TCL1 activates the endoplasmic reticulum stress response: A novel mechanism of leukemic progression in mice. Blood 2012, 120, 1027-1038.

185. Tang, C.H.; Ranatunga, S.; Kriss, C.L.; Cubitt, C.L.; Tao, J.; Pinilla-Ibarz, J.A.; del Valle, J.R.; $\mathrm{Hu}$, C.C. Inhibition of ER stress-associated IRE-1/XBP-1 pathway reduces leukemic cell survival. J. Clin. Investig. 2014, 124, 2585-2598.

186. Kato, H.; Nakajima, S.; Saito, Y.; Takahashi, S.; Katoh, R.; Kitamura, M. mTORC1 serves ER stress-triggered apoptosis via selective activation of the IRE1-JNK pathway. Cell Death Differ. 2012, 19, 310-320.

187. Lloberas, N.; Cruzado, J.M.; Franquesa, M.; Herrero-Fresneda, I.; Torras, J.; Alperovich, G.; Rama, I.; Vidal, A.; Grinyo, J.M. Mammalian target of rapamycin pathway blockade slows progression of diabetic kidney disease in rats. J. Am. Soc. Nephrol. 2006, 17, 1395-1404.

188. Sakaguchi, M.; Isono, M.; Isshiki, K.; Sugimoto, T.; Koya, D.; Kashiwagi, A. Inhibition of mTOR signaling with rapamycin attenuates renal hypertrophy in the early diabetic mice. Biochem. Biophys. Res. Commun. 2006, 340, 296-301.

189. Sataranatarajan, K.; Mariappan, M.M.; Lee, M.J.; Feliers, D.; Choudhury, G.G.; Barnes, J.L.; Kasinath, B.S. Regulation of elongation phase of mRNA translation in diabetic nephropathy: Amelioration by rapamycin. Am. J. Pathol. 2007, 171, 1733-1742.

190. Yang, Y.; Wang, J.; Qin, L.; Shou, Z.; Zhao, J.; Wang, H.; Chen, Y.; Chen, J. Rapamycin prevents early steps of the development of diabetic nephropathy in rats. Am. J. Nephrol. 2007, 27, 495-502.

191. Mori, H.; Inoki, K.; Masutani, K.; Wakabayashi, Y.; Komai, K.; Nakagawa, R.; Guan, K.L.; Yoshimura, A. The mTOR pathway is highly activated in diabetic nephropathy and rapamycin has a strong therapeutic potential. Biochem. Biophys. Res. Commun. 2009, 384, 471-475.

192. Murakami, N.; Riella, L.V.; Funakoshi, T. Risk of metabolic complications in kidney transplantation after conversion to mTOR inhibitor: A systematic review and meta-analysis. Am. J. Transpl. 2014, 14, 2317-2327. 
193. Kudo, T.; Kanemoto, S.; Hara, H.; Morimoto, N.; Morihara, T.; Kimura, R.; Tabira, T.; Imaizumi, K.; Takeda, M. A molecular chaperone inducer protects neurons from ER stress. Cell Death Differ. 2008, 15, 364-375.

194. Prachasilchai, W.; Sonoda, H.; Yokota-Ikeda, N.; Ito, K.; Kudo, T.; Imaizumi, K.; Ikeda, M. The protective effect of a newly developed molecular chaperone-inducer against mouse ischemic acute kidney injury. J. Pharmacol. Sci. 2009, 109, 311-314.

195. Boyce, M.; Bryant, K.F.; Jousse, C.; Long, K.; Harding, H.P.; Scheuner, D.; Kaufman, R.J.; Ma, D.; Coen, D.M.; Ron, D.; et al. A selective inhibitor of eIF2alpha dephosphorylation protects cells from ER stress. Science 2005, 307, 935-939.

196. Wu, C.T.; Sheu, M.L.; Tsai, K.S.; Chiang, C.K.; Liu, S.H. Salubrinal, an eIF2alpha dephosphorylation inhibitor, enhances cisplatin-induced oxidative stress and nephrotoxicity in a mouse model. Free Radic. Biol. Med. 2011, 51, 671-680.

197. Hur, K.Y.; So, J.S.; Ruda, V.; Frank-Kamenetsky, M.; Fitzgerald, K.; Koteliansky, V.; Iwawaki, T.; Glimcher, L.H.; Lee, A.H. IRE1alpha activation protects mice against acetaminophen-induced hepatotoxicity. J. Exp. Med. 2012, 209, 307-318.

198. Lakshmanan, A.P.; Thandavarayan, R.A.; Palaniyandi, S.S.; Sari, F.R.; Meilei, H.; Giridharan, V.V.; Soetikno, V.; Suzuki, K.; Kodama, M.; Watanabe, K. Modulation of AT-1R/CHOP-JNK-caspase12 pathway by olmesartan treatment attenuates ER stress-induced renal apoptosis in streptozotocin-induced diabetic mice. Eur. J. Pharm. Sci. 2011, 44, 627-634.

199. Sun, H.L.; Sun, L.; Li, Y.Y.; Shao, M.M.; Cheng, X.Y.; Ge, N.; Lu, J.D.; Li, S.M. ACE-inhibitor suppresses the apoptosis induced by endoplasmic reticulum stress in renal tubular in experimental diabetic rats. Exp. Clin. Endocrinol. Diabetes 2009, 117, 336-344.

200. Hartner, A.; Cordasic, N.; Klanke, B.; Menendez-Castro, C.; Veelken, R.; Schmieder, R.E.; Hilgers, K.F. Renal protection by low dose irbesartan in diabetic nephropathy is paralleled by a reduction of inflammation, not of endoplasmic reticulum stress. Biochim. Biophys. Acta 2014, $1842,558-565$.

201. Wang, W.; Qiu, L.; Howard, A.; Solis, N.; Li, C.; Wang, X.; Kopp, J.B.; Levi, M. Protective effects of aliskiren and valsartan in mice with diabetic nephropathy. J. Renin. Angiotensin Aldosterone Syst. 2014, 15, 384-395.

202. Tsuda, H.; Kawada, N.; Kaimori, J.Y.; Kitamura, H.; Moriyama, T.; Rakugi, H.; Takahara, S.; Isaka, Y. Febuxostat suppressed renal ischemia-reperfusion injury via reduced oxidative stress. Biochem. Biophys. Res. Commun. 2012, 427, 266-272.

203. Lee, H.J.; Jeong, K.H.; Kim, Y.G.; Moon, J.Y.; Lee, S.H.; Ihm, C.G.; Sung, J.Y.; Lee, T.W. Febuxostat ameliorates diabetic renal injury in a streptozotocin-induced diabetic rat model. Am. J. Nephrol. 2014, 40, 56-63.

204. Wang, C.; Wu, M.; Arvapalli, R.; Dai, X.; Mahmood, M.; Driscoll, H.; Rice, K.M.; Blough, E. Acetaminophen attenuates obesity-related renal injury through ER-mediated stress mechanisms. Cell Physiol. Biochem. 2014, 33, 1139-1148. 
205. Oslowski, C.M.; Urano, F. Measuring ER stress and the unfolded protein response using mammalian tissue culture system. Methods Enzymol. 2011, 490, 71-92.

(C) 2015 by the authors; licensee MDPI, Basel, Switzerland. This article is an open access article distributed under the terms and conditions of the Creative Commons Attribution license (http://creativecommons.org/licenses/by/4.0/). 